\title{
Protective role of Pandanus tectorius Parkinson ex Du Roi in diabetes, hyperlipidemia, liver and kidney dysfunction in alloxan diabetic rats
}

\author{
Saima Sundus ${ }^{1}$, Khan Hira ${ }^{2}$, Nida Sohail ${ }^{3}$, Habiba ${ }^{1}$, Amna Tariq ${ }^{1}$, Jehan Ara', Viqar Sultana ${ }^{3 *}$ and \\ Syed Ehteshamul-Haque ${ }^{4}$
}

\begin{abstract}
Background: Diabetes mellitus (DM), an endocrine disease is characterized by increased level of blood glucose. Diabetes may affect other functions of the body and organs including, renal function and lipid metabolism. Pandanus tectorius (P. tectorius) Parkinson ex Du Roi is a small tree used in folk medicine in treatment of many diseases.
\end{abstract}

Methods: Diabetes in rats was induced by intraperitoneal injection of alloxan at a dose of $100 \mathrm{mg} / \mathrm{kg}$ body weight for 3 days. Water and ethanol extracts of root, stem and leave of $P$. tectorius were given to rats at $200 \mathrm{mg} / \mathrm{kg}$ body weight at day 3. Rats were sacrificed on day 4 after $12 \mathrm{~h}$ fasting. Serum glucose and other biochemical parameters like liver enzymes; [alanine aminotransferases (ALT), aspartate aminotransferases (AST), alkaline phosphatase (ALP) and lactate dehydrogenase (LDH)], kidney parameters (urea \& creatinine), lipid profile [total cholesterol, HDL and LDL cholesterol and triglycerides] and coronary artery risk index (CRI) were estimated in blood serum. Antioxidant potential, polyphenol content and phytochemical constituents in different parts of $P$. tectorius were also determined.

Results: Results showed that water extract of stem and ethanol extract of root of $P$. tectorius produced maximum fall in sugar level of alloxan diabetic rats. Extracts of all three plant parts significantly dropped the increased level of urea and creatinine with maximum reduction in creatinine was observed by water extract of root. P.tectorius extracts showed positive effect on liver enzymes and lipid profile by bringing them closer to normal range in comparison to alloxan diabetic control rats. Phytochemical screening indicated presence of flavonoids, alkaloids, tannins and saponin in P. tectorius. In DPPH free radical scavenging test the highest antioxidant potential was found in water extract of roots, while ethanol extract of stem also showed good activity.

Conclusion: The study demonstrated that different parts of P.tectorius have potential to attenuate diabetes and diabetes related complications like, liver, kidney dysfunction and lipid metabolism.

Keywords: Pandanus tectorius Parkinson ex Du Roi, Alloxan, Diabetes mellitus, Enzymes, Nephrotoxicity, Lipid profile

\footnotetext{
* Correspondence: viqarsultana98@hotmail.com

${ }^{3}$ Department of Biochemistry, University of Karachi, Karachi 75270, Pakistan

Full list of author information is available at the end of the article
}

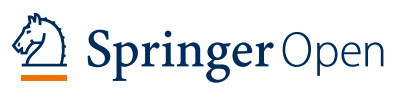

(c) The Author(s). 2021 Open Access This article is licensed under a Creative Commons Attribution 4.0 International License, which permits use, sharing, adaptation, distribution and reproduction in any medium or format, as long as you give appropriate credit to the original author(s) and the source, provide a link to the Creative Commons licence, and indicate if changes were made. The images or other third party material in this article are included in the article's Creative Commons licence, unless indicated otherwise in a credit line to the material. If material is not included in the article's Creative Commons licence and your intended use is not permitted by statutory regulation or exceeds the permitted use, you will need to obtain permission directly from the copyright holder. To view a copy of this licence, visit http://creativecommons.org/licenses/by/4.0/. 


\section{Introduction}

Diabetes mellitus (DM) type 2, a metabolic disorder is characterized by the abnormal increase of sugar (glucose) in blood due to insufficient production of insulin by pancreas [1]. Hyperglycemia may affect other body functions and organs, especially kidney, heart, eyes, veins and nerves [2]. Pathogenesis of diabetes mellitus is directly proportional to the decreased antioxidant status of the body [3]. The free radicals (superoxide dismutase, hydrogen peroxide etc.) cause devastation of $\beta$ cells of pancreas and at last diminished insulin production [4]. The disease may bring about weak digestion of glucose and different biomolecules like lipids, carbohydrates and proteins [5]. According to some estimations type 2 diabetes mellitus has an impact on 415 million people in 2015 and this will increase up to 642 million by 2040 [6]. Different drugs like; sulphonylureas, biguanides, thiazolidinediones and insulin are available to treat diabetes and reduce the risk of complications [7]. Despite remarkable development for treating diabetes by oral hypoglycemic drugs, investigations for new drugs continue, as the existing synthetic drugs have several safety issues [8].

Herbal medicines derived from plants have been utilized for the therapy of type 2 diabetes mellitus [9]. Pandanus tectorius Parkinson ex Du Roi is a little tree grown wild in littoral habitats all through the coast of South and Southeast Asia, Australia and Pacific islands of Oceania [10]. In folk medicine, different parts of this plant have been used for the treatment of bronchitis, leprosy, dermatitis, measles, urinary tract ailments and type 2 diabetes mellitus [11]. Its leaves have been used for alleviating hepatitis, asthma, cold and cancer, where its roots were found helpful in managing digestive and respiratory disorders [12]. Ten phenolic compounds isolated from $P$. tectorius, out of which vanillin showed strong antioxidant activity [13]. Various medicinal properties of P.tectorius have been reported but, scientific evaluation of these properties received little attention. The present research describes the anti-diabetic, nephron-protective and hypolipidemic activity of water and ethanol extracts of various parts of $P$. tectorius in alloxan diabetic rats.

\section{Materials and methods Chemicals and reagents}

Solvent (ethanol) of analytical grades was purchased from Merck (France). Alloxan, DPPH and Tris (hydroxymethyl) aminomethane were purchased from Sigma Aldrich, U.S.A. All the kits including ALAT, AST, ALP, LDH, urea, creatinine glucose, triglycerides, cholesterol, HDL cholesterol, LDL cholesterol were purchased from Merck (France) and Ecoline (Germany).

\section{Collection of plant material}

Pandanus tectorius Parkinson ex Du Roi was collected from Bali Bagh, Malir, Karachi. Fresh plant part of $P$. tectorius (root, stem and leaf) were cleaned with the tap water and stored at $-20^{\circ} \mathrm{C}$ until used. Herbarium sheet was kept in the Department of Botany, University of Karachi, bearing herbarium No. 14/2/2014, G.H: 86550.

\section{Preparation of ethanol extract of different parts of Pandanus tectorius Parkinson ex Du Roi}

Different parts of $P$. tectorius, leaf, root and stem (500 g each) were cut into small pieces with a knife and then chopped in an electric grinder. The minced material of each part was soaked for 2 weeks in distilled ethanol (96\%) and filtered over cotton wool. The filtrate was concentrated to a gummy mass on a rotary vacuum evaporator (Büchi R-200, New Castle, DE) that give the yield of $2.7 \%$ from stem, $9.5 \%$ from root and $7.5 \%$ from leaves respectively. Extracts were stored at a room temperature until used.

\section{Preparation of water extract from different parts of Pandanus tectorius Parkinson ex Du Roi}

The Leaves, root and stem (100 g each) of P.tectorius were cut separately and grinded, soaked in distilled water for $1 \mathrm{~h}$ and homogenized using a homogenizer (Polytron (Kinematica) PT-MR 2100), then filtered over through Whatman no. 1 filter paper. The filtrate was lyophilized on a freeze dryer (Eyela, FD-1) that gave the yield of $14.5 \%$ from stem, $11.6 \%$ from root and $2.6 \%$ from leaves and stored at $-20{ }^{\circ} \mathrm{C}$ until used.

\section{Animals}

Male (Wistar albino) rats, of body weight 150-200 g were bought from Dow University of Health Science, Karachi. Rats were then kept in cages under standard laboratory conditions $\left(23 \pm 2{ }^{\circ} \mathrm{C}\right.$ and $12 \mathrm{~h}$ light/dark cycle $)$ for 2 weeks prior to experimentation. All the animals were fed with a standard pellet diet and water (ad libitum).

\section{Induction of diabetes mellitus}

Diabetes in rats was produced by using method of Zhang et al. [14], where intraperitoneal injection of alloxan monohydrate (Sigma aldrich, St. Louis, MO) at $100 \mathrm{mg}$ / $\mathrm{kg} \mathrm{BW}$ in saline was given to rats for 3 days continuously. The sugar level was evaluated on the third day by using a glucometer (Gluco trend Roche). The level of blood sugar $250 \mathrm{mg} / \mathrm{dl}$ or above was considered as diabetic. 
Effect of ethanol extract of different parts of Pandanus tectorius Parkinson ex Du Roi in normal and alloxan diabetic rat's model

The rats were separated into 3 major groups, where the third group was further divided into 6 sub-groups with each consisting of 6 rats.

$>$ Normal control group: This group of rats was fed on standard diet and water with no treatment.

$>$ Alloxan diabetic control group: This group of rats was intraperitoneally injected with alloxan $(100 \mathrm{mg} / \mathrm{kg})$ for 3 days.

$>$ Ethanol extract of P.tectorius treated group rats: This group of rats was further separated into 6 sub-groups:

- Ethyl alcohol extract of leaves of P.tectorius treated group: This group of rats was orally dosed with ethanol extract of leaves of P.tectorius $(200 \mathrm{mg} / \mathrm{kg}$ b.w.,) at day 3 .

- Ethyl alcohol extract of stem of P.tectorius treated group: This group of rats was orally dosed with ethanol extract of stem of P.tectorius $(200 \mathrm{mg} / \mathrm{kg}$ b.w.,) at day 3 .

- Ethyl alcohol extract of roots of P.tectorius treated group: This group of rats was orally dosed with ethanol extract of roots of P.tectorius $(200 \mathrm{mg} / \mathrm{kg}$ b.w.,) at day 3 .

- Ethyl alcohol extract of leaves of P.tectorius + alloxan dosed group: This group of rats were intraperitoneally injected with alloxan $(100 \mathrm{mg} / \mathrm{kg})$ for 3 days. On day 3 they were fed with ethanol extract of leaves of P.tectorius ( $200 \mathrm{mg} / \mathrm{kg}$ b.w.).

- Ethyl alcohol extract of stem of P. tectorius + alloxan dosed group: This group of rats were intraperitoneally injected with alloxan $(100 \mathrm{mg} / \mathrm{kg})$ for 3 days. On day 3 they were fed with ethanol extract from the stem of P.tectorius $(200 \mathrm{mg} / \mathrm{kg}$ b.w.,).

- Ethyl alcohol extract of roots of P. tectorius + alloxan dosed group: This group of rats were intraperitoneally injected with alloxan $(100 \mathrm{mg} / \mathrm{kg})$ for 3 days. At day 3 they were fed with ethanol extract of roots of P. tectorius ( $200 \mathrm{mg} / \mathrm{kg} \mathrm{b.w}$ ).

On the 4th day, rats from each group were decapitated after $12 \mathrm{~h}$ fasting [14]. After collection of Blood, serum was obtained by centrifugation to do biochemical analysis.

Effect of water extract of different parts of Pandanus tectorius Parkinson ex Du Roi in normal and alloxan diabetic rat's model

Details are same as described in the section of "Effect of ethanol extract of different parts of Pandanus tectorius Parkinson ex Du Roi in normal and alloxan diabetic rats' model", except extract of water was used as an alternative of ethanol extracts of different parts of $P$. tectorius.

\section{Assessment of anti-diabetic, nephron-protective and cardio-protective effect of $P$. tectorius}

Anti-diabetic effect was evaluated by estimating blood glucose level; while nephro-protective effect was determined by using kidney profile (urea and creatinine); whereas cardio-protective effect was examined using hepatic enzyme including i) alanine aminotransferases (ALAT), ii) aspartate aminotransferases (AST), iii) alkaline phosphatase (ALP), iv) lactate dehydrogenase (LDH). Lipid profile i) total cholesterol, ii) triglycerides, iii) HDL cholesterol iv) LDL cholesterol was also determined and coronary artery risk index (CRI) and atherogenic index (AI) were calculated [15]. All estimations were performed on a blood chemistry analyzer (Micro lab 300 (Merck)\}using kits (Merck / Ecoline).

\section{Antioxidant activity of ethanol and water extracts of $P$. tectorius}

Free radical capturing capacity of extracts of water and ethanol of different parts of $P$. tectorius were estimated using 2, 2-Diphenyl-1-picrylhydrazyl (DPPH) assay [16]. Where $200 \mu \mathrm{L}$ of each extract having $0.002,0.05$, and $0.01 \mathrm{mg} / \mathrm{ml}$ concentration was mixed with $800 \mu \mathrm{l}$ of 100 $\mathrm{mM}$ Tris- $\mathrm{HCl}$ buffer ( $\mathrm{pH}$ 7.4). DPPH (30 $\mu \mathrm{M}$ dissolved in DMSO), $1 \mathrm{~mL}$ was added to the mixture and vortex. The absorbance was recorded at $517 \mathrm{~nm}$ against blank by using UV-visible spectrophotometer. One $\mathrm{ml}$ ethanol in $1 \mathrm{ml} \mathrm{DPPH}$ was used as control. Below mentioned formula was used to calculate the activity.

(\%) Antioxidant activity $=\frac{\text { Absorbance of control-Absorbance of sample }}{\text { Absorbance of control }} \times 100$

\section{Estimation the phytochemical constituents}

For the determination of different phytochemicals in leaves, stem and roots of $P$. tectorius standard methods were used. Polyphenol were extracted from water and ethanol of different parts (root, stem, leaves) of P. tectorius by using the method of Jimenez-Escrig et al. [17] and estimated by Chandini et al. [18]. Alkaloids were estimated according to the method of Harborne [19]. Obdoni \& Ochuko [20] method was used to estimate saponin. Total tannin was estimated by using the method of Julkunen-Tiitto [21]. Whereas, method of Chang et al. [22] was used for the determination of flavonoid.

\section{Statistical analysis}

To analyze the data "Analysis of Variance" (ANOVA) was used and means were compared at [23]. Duncan's 
Multiple Range Test was also performed and means \pm SD was calculated.

\section{Results}

Preventive effect of water extract of $P$. tectorius in diabetic and normal rats model

When alloxan was administered, significant increment $(P<0.05)$ of the glucose level in blood as compared to normal control rats was observed. Extracts of water of all three plant parts produced reduction in glucose level towards normal range like root $(-61.6 \%)$ stem $(-65.9 \%)$ and leaves $(-39.3 \%)$ in comparison to diabetic control groups. Water extract of root $(-21.68 \%)$ and stem ($20.97 \%$ ) also showed reduction in glucose level in comparison with normal control (Table 1).

The effect of alloxan also resulted in a significant $(P<$ 0.05 ) increase in level of kidney markers (creatinine and urea) when compared to normal control rats. A significant drop in urea and creatinine levels in the extracts of all three parts and remarkable reduction in creatinine was observed by root extract $(-36.1 \%)$ when compared to diabetic control group. Water extract of leave and root extract did not show any effect on urea while creatinine concentration was reduced in root $(-43.4 \%)$ and stem extracts $(-71.3 \%)$ in comparison to normal control rats (Table 1).

Alloxan, besides affecting glucose metabolism it has also disturbed lipid profile and increase in total cholesterol, triglycerides and LDL-cholesterol with lowering in HDL-cholesterol in comparison to normal rat's model. In diabetic animals' administration of water extract of root, stem and leave decreased the alloxan-induced elevated concentration of triglyceride, total cholesterol, and LDL-cholesterol with increased in HDL-cholesterol towards normal range. Alloxan treatment increased the CRI and AI in diabetic control rats; however, treatment with water extract of root, stem and leave reduced the indexes. Maximum reduction in CRI and AI was observed by water extract of stem (Table 2). Water extract from all three parts of plant positively impact lipid profile and reduced serum cholesterol, triglycerides (TG) and low-density lipoprotein cholesterol (LDL-c) with subsequent increased in high density lipoprotein cholesterol (HDL-c) except water extract of leave (Table 2).

Administration of alloxan also disturbed cardiac and liver enzymes and increased ALAT, ALP, ASAT, LDH as compared to normal control rats. Treatment with water extracts from root, stem and leave dropped the elevated level of all enzymes markedly. Highest lowering effect was produced by the water extract of stem, ALAT (-50.6\%), ASAT (-28.8\%), ALP (-53.4) and LDH $(-20.7 \%)$ close to normal control rats (Table 3$)$.

\section{Preventive effect of ethanol extract of $P$. tectorius in diabetic and normal rats model}

Treatment with ethanol extracts of root, stem and leaf showed marked reduction in glucose concentration respectively $(-48.8 \%),(-31.33 \%)$ and $(-16.4 \%)$ in alloxan diabetic rats as compared to diabetic alone groups. Whereas, ethanol extracts of root and stem also significantly reduced glucose in normal rats in comparison to normal control rats. Urea and creatinine concentrations were also significantly decreased by the all three ethanol extracts ranging from creatinine $(-71.42 \%$ to $-89.86 \%)$ and urea $(-24.37 \%$ to $50.0 \%)$ in comparison to diabetic control groups. Significant decrease in creatinine and urea levels were also found by the ethanol extract of root when compared with normal control rats. Root extract was ranked top with respect to overall effect on glucose and kidney markers (Table 4).

Treatment with alloxan again resulted in significant hypercholesterolemia and hypertriglyceridemia with lowering of HDL-cholesterol in comparison to normal control animals. Treatment with ethanol extract from

Table 1 Effect of water extract of different parts of Pandanus tectorius Parkinson ex Du Roi on blood glucose level and kidney markers in normal and diabetic rat's model

\begin{tabular}{|c|c|c|c|c|c|c|}
\hline \multirow[t]{2}{*}{ Treatments } & \multicolumn{3}{|l|}{ Normal Rats Model } & \multicolumn{3}{|c|}{ Diabetic Rats Model } \\
\hline & Glucose mg/dl & Creatinine $\mathrm{mg} / \mathrm{dl}$ & Urea mg/dl & Glucose mg/dl & Creatinine $\mathrm{mg} / \mathrm{dl}$ & Urea mg/dl \\
\hline Control & $95.33^{b} \pm 2.51$ & $0.23^{a} \pm 0.05$ & $48^{a} \pm 2$ & $391^{a} \pm 8.5$ & $1.66^{a} \pm 0.11$ & $139^{a} \pm 1$ \\
\hline $\begin{array}{l}\text { Water extract of } \\
\text { root }\end{array}$ & $\begin{array}{l}74.66^{\complement} \pm 1.15(- \\
21.68 \%)\end{array}$ & $\begin{array}{l}0.13^{\mathrm{ab}} \pm 0.05(- \\
43.47 \%)\end{array}$ & $\begin{array}{l}47.33^{\mathrm{a}} \pm 1.52(- \\
1.45 \%)\end{array}$ & $\begin{array}{l}150^{C} \pm 5(- \\
61.6 \%)\end{array}$ & $\begin{array}{l}1.06^{\mathrm{b}} \pm 0.05(- \\
36.14 \%)\end{array}$ & $\begin{array}{l}38.33^{d} \pm 1.52(- \\
72.42 \%)\end{array}$ \\
\hline $\begin{array}{l}\text { Water extract of } \\
\text { stem }\end{array}$ & $\begin{array}{l}75.33^{\mathrm{C}} \pm 0.57(- \\
20.97 \%)\end{array}$ & $\begin{array}{l}0.16 a^{b} \pm 0.05(- \\
30.43 \%)\end{array}$ & $\begin{array}{l}33^{b} \pm 1.73(- \\
31.25 \%)\end{array}$ & $\begin{array}{l}133^{\mathrm{d}} \pm 2(- \\
65.98 \%)\end{array}$ & $\begin{array}{l}1.16^{b} \pm 0.15(- \\
30.12 \%)\end{array}$ & $\begin{array}{l}41.66^{\mathrm{cd}} \pm 4.72(- \\
70.02 \%)\end{array}$ \\
\hline $\begin{array}{l}\text { Water extract of } \\
\text { leave }\end{array}$ & $101^{\mathrm{a}} \pm 2.51(+5.9 \%)$ & $0.23^{a} \pm 0.05(0 \%)$ & $\begin{array}{l}47.66^{\mathrm{a}} \pm 3.7(- \\
0.7 \%)\end{array}$ & $\begin{array}{l}237^{\mathrm{b}} \pm 5(- \\
39.38 \%)\end{array}$ & $\begin{array}{l}1.23^{\mathrm{b}} \pm 0.37(- \\
25.90 \%)\end{array}$ & $\begin{array}{l}93.33^{\mathrm{b}} \pm 1.52(- \\
32.85 \%)\end{array}$ \\
\hline $\mathrm{LSD}_{0.05}$ & 6.12 & 0.11 & 4.57 & 9.2 & 0.36 & 5.03 \\
\hline
\end{tabular}

Mean values in column bearing same superscript letters are not significantly different $(p<0.05)$ according to Duncan's Multiple Range Test

Mean values in columns showing differences greater than LSD values are significantly different at $p<0.05$

Values are mean \pm Standard deviation with $n=6$

Values in parenthesis are showing percent increased or decreased as compared to their respective control 


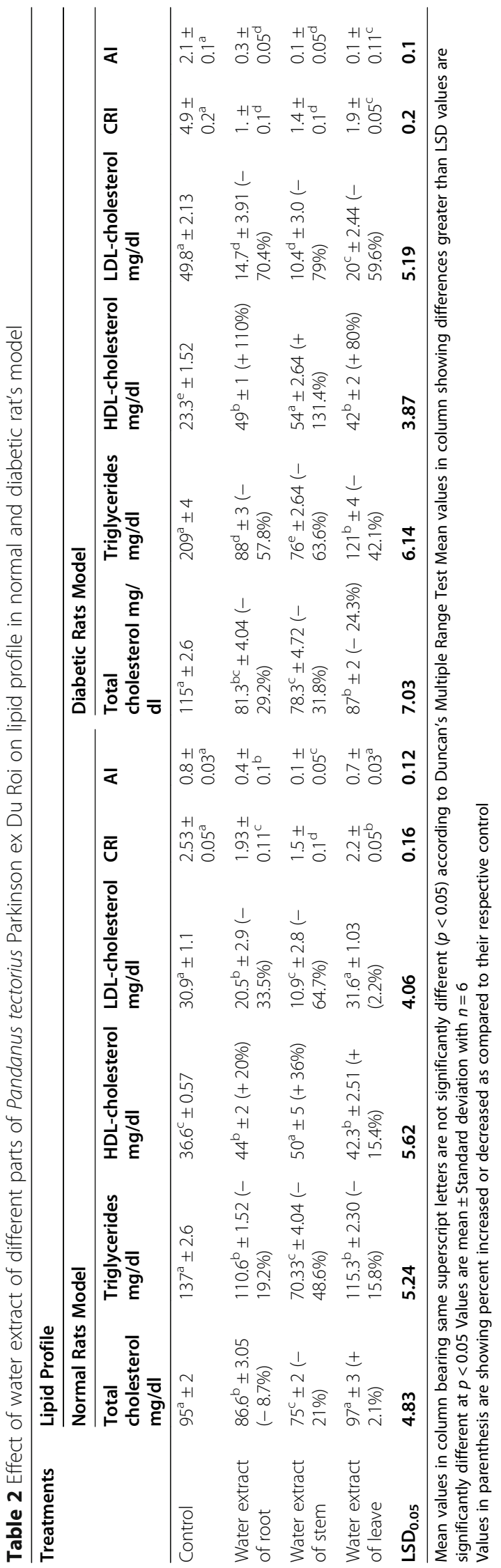


Table 3 Effect of water extract of different parts of Pandanus tectorius Parkinson ex Du Roi on liver and cardiac enzymes in normal and diabetic rat's model

\begin{tabular}{|c|c|c|c|c|c|c|c|c|}
\hline \multirow[t]{3}{*}{ Treatments } & \multicolumn{8}{|l|}{ Enzymes } \\
\hline & \multicolumn{4}{|c|}{ Normal Rats Model } & \multicolumn{4}{|c|}{ Diabetic Rats Model } \\
\hline & $\begin{array}{l}\text { ALAT } \\
\text { U/L }\end{array}$ & $\begin{array}{l}\text { ASAT } \\
\text { U/L }\end{array}$ & $\begin{array}{l}\text { ALP } \\
\text { U/L }\end{array}$ & $\begin{array}{l}\mathrm{LDH} \\
\mathrm{U} / \mathrm{L}\end{array}$ & $\begin{array}{l}\text { ALAT } \\
\text { U/L }\end{array}$ & $\begin{array}{l}\text { ASAT } \\
\text { U/L }\end{array}$ & $\begin{array}{l}\text { ALP } \\
\text { U/L }\end{array}$ & $\begin{array}{l}\text { LDH } \\
\text { U/L }\end{array}$ \\
\hline Control & $35^{\mathrm{a}} \pm 2$ & $144.3^{\mathrm{a}} \pm 4.72$ & $22^{\mathrm{a}} \pm 2$ & $48^{a} \pm 2$ & $45^{a} \pm 5$ & $130.66^{a} \pm 6.65$ & $138.3^{\mathrm{a}} \pm 4.16$ & $282.66^{a} \pm 1.52$ \\
\hline $\begin{array}{l}\text { Water extract } \\
\text { of root }\end{array}$ & $\begin{array}{l}20^{b} \pm 1(- \\
42.8 \%)\end{array}$ & $\begin{array}{l}109.6^{\mathrm{C}} \pm 3.51(- \\
23.8 \%)\end{array}$ & $\begin{array}{l}18.6^{\mathrm{a}} \pm 4.50(- \\
15 \%)\end{array}$ & $\begin{array}{l}198.3^{\mathrm{b}} \pm 1.52(- \\
313.1 \%)\end{array}$ & $\begin{array}{l}25.6^{c} \pm 2.08(+ \\
42.9 \%)\end{array}$ & $\begin{array}{l}101^{\mathrm{C}} \pm 3.46(- \\
22.7 \%)\end{array}$ & $\begin{array}{l}114.6^{\mathrm{b}} \pm 4.6 \\
(-17.1 \%)\end{array}$ & $\begin{array}{l}198^{e} \pm 8(- \\
29.9 \%)\end{array}$ \\
\hline $\begin{array}{l}\text { Water extract } \\
\text { of stem }\end{array}$ & $\begin{array}{l}17^{b} \pm 2(- \\
51.4 \%)\end{array}$ & $\begin{array}{l}125^{\mathrm{b}} \pm 2.6(- \\
13.3 \%)\end{array}$ & $\begin{array}{l}19.3^{\mathrm{a}} \pm 0.5(- \\
12.1 \%)\end{array}$ & $\begin{array}{l}245^{a} \pm 4(+ \\
410.4 \%)\end{array}$ & $\begin{array}{l}22.3^{c} \pm 2.51(- \\
50.6)\end{array}$ & $\begin{array}{l}93^{d} \pm 3(- \\
28.8 \%)\end{array}$ & $\begin{array}{l}64.3^{c} \pm 4.3(- \\
53.5)\end{array}$ & $\begin{array}{l}224 c \pm 5.5(- \\
20.7 \%)\end{array}$ \\
\hline $\begin{array}{l}\text { Water extract } \\
\text { of leave }\end{array}$ & $\begin{array}{l}18.3^{b} \pm 1.5(- \\
47.6 \%)\end{array}$ & $\begin{array}{l}110^{c} \pm 2(- \\
23.7 \%)\end{array}$ & $\begin{array}{l}17.6^{\mathrm{a}} \pm 2.08(- \\
19.7 \%)\end{array}$ & $\begin{array}{l}198.3^{\mathrm{b}} \pm 1.52(+ \\
313.1 \%)\end{array}$ & $\begin{array}{l}35^{\mathrm{b}} \pm 4.5(- \\
22.2 \%)\end{array}$ & $\begin{array}{l}137.3^{\mathrm{a}} \pm 3.51(- \\
5.10 \%)\end{array}$ & $\begin{array}{l}135.3^{\mathrm{a}} \pm 4.5(- \\
2.16 \%)\end{array}$ & $\begin{array}{l}273.6^{\mathrm{b}} \pm 3(- \\
3.4 \%)\end{array}$ \\
\hline $\operatorname{LSD}_{0.05}$ & 3.1 & 6.3 & 5.0 & 4.6 & 6.7 & 7.2 & 7.7 & 9.1 \\
\hline
\end{tabular}

Mean values in columns bearing the same superscript letters are not significantly different $(p<0.05)$ according to Duncan's Multiple Range Test

Mean values in columns showing differences greater than LSD values are significantly different at $p<0.05$

Values are mean \pm Standard deviation with $n=6$

Values in parenthesis are showing percent increased or decreased as compared to their respective control

different parts of the plant significantly decreased these values. Highest increase in HDL-cholesterol $(+112.2 \%)$ and decreased in LDL-cholesterol (-67.37\%) was demonstrated by leaves extract. CRI and AI showed increases in both indexes when treated with alloxan, whereas the level was decreased by three ethanol extracts as compared to diabetic control rats. Whereas, normal control rats in all the three extracts, showed deduction in triglyceride, total cholesterol, and LDL-cholesterol with an increase in HDL-cholesterol (Table 5).

Treatment with ethanol extract of root, stem, and leave, also decreased elevated liver enzymes in alloxan diabetic rats. All the three extracts showed remarkable reduction in enzymes levels, ranging from ALP $(-55.8 \%$ to $-66.7 \%)$, ALAT ( -51.4 to $55.1 \%)$, ASAT $(-21.05 \%$ to $-52.3 \%)$ and LDH (- 19.2 to $51.4 \%$ ) in comparison with diabetic control rats (Table 6). Ethanol extract of root was also found to reduce ALAT (-27.2\%), ASAT (73.3\%), ALP (-21.0\%) and LDH (- 41.8\%) as compared to control rats (Table 6).

\section{Determination of antioxidant activity in water and ethanol extracts of $P$. tectorius}

In order to determine activity of antioxidants in water extract different concentrations $0.002,0.01$, and 0.05 $\mathrm{mg} / \mathrm{ml}$ were used (Fig. 1). The effectivity was concentration dependent. The highest activity was found in root $(34.2 \%)$ at 0.05 concentrations, which was followed by stem (27.4\%) and leave (19.7\%) at the same concentration level. Root extract at $0.05 \mathrm{mg} / \mathrm{ml}$ concentration showed activity (34.2\%) slightly higher than the standard ascorbic acid (31.06\%). Lowest activity was recorded by leaf extract.

Table 4 Effect of ethanol extract of different parts of Pandanus tectorius Parkinson ex Du Roi on blood glucose level and kidney markers in normal and diabetic rat's model

\begin{tabular}{|c|c|c|c|c|c|c|}
\hline \multirow[t]{2}{*}{ Treatments } & \multicolumn{3}{|c|}{ Normal Rats Model } & \multicolumn{3}{|c|}{ Diabetic Rats Model } \\
\hline & Glucose mg/dl & $\begin{array}{l}\text { Creatinine mg/ } \\
\text { dl }\end{array}$ & Urea mg/dl & Glucose mg/dl & Creatinine $\mathrm{mg} / \mathrm{dl}$ & Urea mg/dl \\
\hline Control & $97.3^{a} \pm 1.5$ & $1^{a} \pm 0$ & $47.6^{a} \pm 4.7$ & $250^{a} \pm 6$ & $1.26^{a} \pm 0.2$ & $105.3^{a} \pm 3.7$ \\
\hline $\begin{array}{l}\text { Ethanol extract of } \\
\text { root }\end{array}$ & $\begin{array}{l}66.6^{\mathrm{b}} \pm 2.5(- \\
31.5 \%)\end{array}$ & $\begin{array}{l}0.83^{b} \pm 0.1(- \\
17 \%)\end{array}$ & $\begin{array}{l}25.6^{c} \pm 3.5(- \\
46.1 \%)\end{array}$ & $\begin{array}{l}128^{\mathrm{d}} \pm 2.8(- \\
48.8 \%)\end{array}$ & $0.13^{c} \pm 0.05(-89.8 \%)$ & $\begin{array}{l}52.6^{c} \pm 2.5(- \\
50.0 \%)\end{array}$ \\
\hline $\begin{array}{l}\text { Ethanol extract of } \\
\text { stem }\end{array}$ & $76^{b} \pm 3(-21.9 \%)$ & $1.03^{a} \pm 0.1(+3 \%)$ & $\begin{array}{l}36.6^{b} \pm 4.1(- \\
23.1 \%)\end{array}$ & $\begin{array}{l}171.6^{c} \pm 4.0(- \\
31.3 \%)\end{array}$ & $0.36^{\mathrm{b}} \pm 0.11(-71.4 \%)$ & $\begin{array}{l}79.6^{\mathrm{b}} \pm 4.50(- \\
24.3 \%)\end{array}$ \\
\hline $\begin{array}{l}\text { Ethanol extract of } \\
\text { leave }\end{array}$ & $95^{\complement} \pm 6.2(-2.3 \%)$ & $1^{a} \pm 0(0 \%)$ & $\begin{array}{l}39.3^{b} \pm 2.8(- \\
17.47 \%)\end{array}$ & $\begin{array}{l}209^{b} \pm 4.3(- \\
16.4 \%)\end{array}$ & $\begin{array}{l}0.26^{b c} \pm 0.05(- \\
79.36 \%)\end{array}$ & $58^{\complement} \pm 4(-44.9 \%)$ \\
\hline $\operatorname{LSD}_{0.05}$ & 7.0 & 0.1 & 7.3 & 7.4 & 0.2 & 6.4 \\
\hline
\end{tabular}

Mean values in columns bearing the same superscript letters are not significantly different $(p<0.05)$ according to Duncan's Multiple Range Test

Mean values in column showing differences greater than LSD values are significantly different at $p<0.05$

Values are mean \pm Standard deviation with $n=6$

Values in parenthesis are showing percent increased or decreased as compared to their respective control 


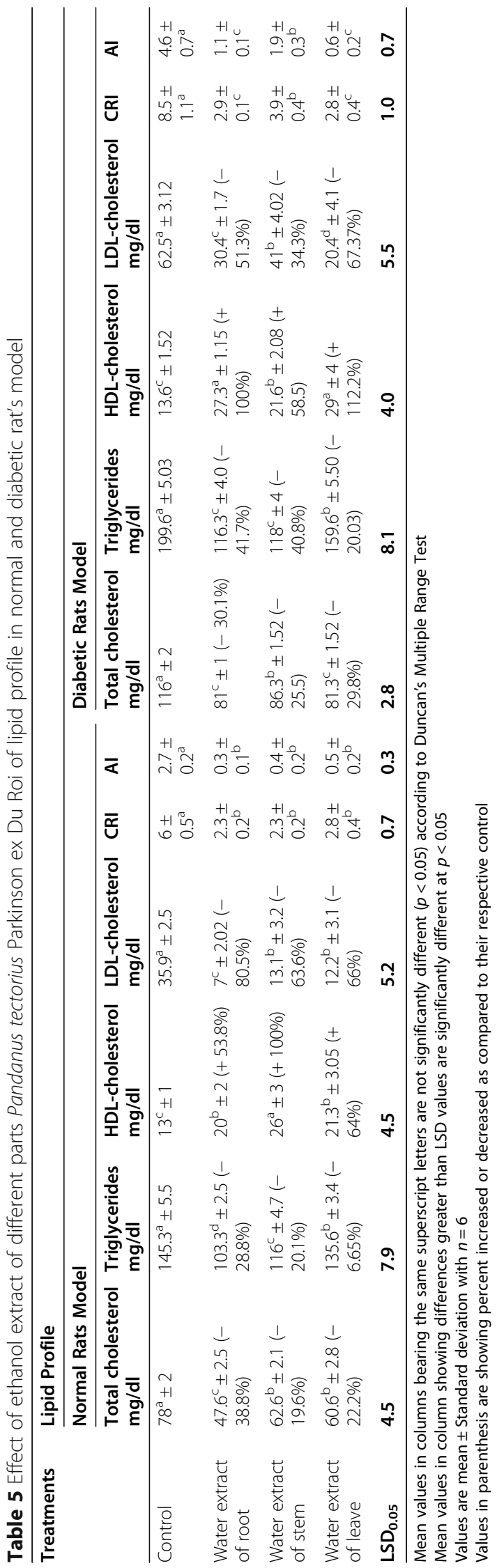


Table 6 Effect of ethanol extract of different parts of Pandanus tectorius Parkinson ex Du Roi on liver and cardiac enzymes in normal and diabetic rat's model

\begin{tabular}{|c|c|c|c|c|c|c|c|c|}
\hline \multirow[t]{3}{*}{ Treatments } & \multicolumn{8}{|l|}{ Enzymes } \\
\hline & \multicolumn{4}{|c|}{ Normal Rats Model } & \multicolumn{4}{|c|}{ Diabetic Rats Model } \\
\hline & $\begin{array}{l}\text { ALAT } \\
\text { U/L }\end{array}$ & $\begin{array}{l}\text { ASAT } \\
\text { U/L }\end{array}$ & $\begin{array}{l}\text { ALP } \\
\text { U/L }\end{array}$ & $\begin{array}{l}\mathrm{LDH} \\
\mathrm{U} / \mathrm{L}\end{array}$ & $\begin{array}{l}\text { ALAT } \\
\text { U/L }\end{array}$ & $\begin{array}{l}\text { ASAT } \\
\text { U/L }\end{array}$ & $\begin{array}{l}\text { ALP } \\
U / L\end{array}$ & $\begin{array}{l}\text { LDH } \\
\text { U/L }\end{array}$ \\
\hline Control & $29.3^{a} \pm 4$ & $95^{\mathrm{a}} \pm 4.5$ & $31.6^{a} \pm 2.88$ & $232^{\mathrm{a}} \pm 4.58$ & $45.3^{\mathrm{a}} \pm 5.03$ & $133^{\mathrm{a}} \pm 1.52$ & $94.3^{\mathrm{a}} \pm 5.8$ & $345.3^{a} \pm 3.5$ \\
\hline $\begin{array}{l}\text { Ethanol extract } \\
\text { of root }\end{array}$ & $\begin{array}{l}21.3^{\mathrm{b}} \pm 1.52(- \\
27.2 \%)\end{array}$ & $\begin{array}{l}25.3^{d} \pm 1.52(- \\
73.3 \%)\end{array}$ & $\begin{array}{l}25^{\mathrm{bc}} \pm 1(- \\
21 \%)\end{array}$ & $\begin{array}{l}135^{\mathrm{C}} \pm 3(- \\
41.8 \%)\end{array}$ & $\begin{array}{l}20.3^{c} \pm 4.61(- \\
55.1 \%)\end{array}$ & $\begin{array}{l}105^{\mathrm{b}} \pm 4.5(- \\
21 \%)\end{array}$ & $\begin{array}{l}31.3^{c} \pm 1.2(- \\
66.7 \%)\end{array}$ & $\begin{array}{l}272^{\mathrm{b}} \pm 3(- \\
21.2 \%)\end{array}$ \\
\hline $\begin{array}{l}\text { Ethanol extract } \\
\text { of stem }\end{array}$ & $\begin{array}{l}14.6^{\mathrm{C}} \pm 0.57(- \\
50 \%)\end{array}$ & $\begin{array}{l}58.3^{\mathrm{c}} \pm 8.02(- \\
38.6 \%)\end{array}$ & $\begin{array}{l}21.6^{c} \pm 1.52(- \\
31.5 \%)\end{array}$ & $\begin{array}{l}220^{\mathrm{b}} \pm 8.3(- \\
5.17 \%)\end{array}$ & $\begin{array}{l}21^{\mathrm{C}} \pm 2.6(+ \\
53.6 \%)\end{array}$ & $\begin{array}{l}87^{c} \pm 4.5(- \\
34.5 \%)\end{array}$ & $\begin{array}{l}41.6^{\mathrm{b}} \pm 4.50(+ \\
55.8 \%)\end{array}$ & $\begin{array}{l}167.6^{\mathrm{d}} \pm 8.5(- \\
51.4 \%)\end{array}$ \\
\hline $\begin{array}{l}\text { Ethanol extract } \\
\text { of leave }\end{array}$ & $\begin{array}{l}29^{\mathrm{a}} \pm 4.5(- \\
1.12 \%)\end{array}$ & $\begin{array}{l}82^{b} \pm 5.29(- \\
13.6 \%)\end{array}$ & $\begin{array}{l}29.3^{\mathrm{ab}} \pm 4.61(- \\
7.35 \%)\end{array}$ & $\begin{array}{l}230^{\mathrm{ab}} \pm 4.2(- \\
0.86 \%)\end{array}$ & $\begin{array}{l}22^{\mathrm{c}} \pm 3.6(- \\
51.4 \%)\end{array}$ & $\begin{array}{l}63.3^{\mathrm{d}} \pm 1.52(- \\
52.3 \%)\end{array}$ & $\begin{array}{l}32.6^{c} \pm 2.51(- \\
65.37 \%)\end{array}$ & $\begin{array}{l}279^{\mathrm{b}} \pm 6.8(- \\
19.2 \%)\end{array}$ \\
\hline $\operatorname{LSD}_{0.05}$ & 5. & 10.1 & 5.4 & 10.2 & 6.8 & 6.5 & 6.8 & 9.9 \\
\hline
\end{tabular}

Mean values in column bearing same superscript letters are not significantly different $(p<0.05)$ according to Duncan's Multiple Range Test

Mean values in column showing differences greater than LSD values are significantly different at $p<0.05$

Values are mean \pm Standard deviation with $n=6$

Values in parenthesis are showing percent increased or decreased as compared to their respective control

The antioxidant potential of root, stem and leaf in ethanol extract are given in Fig. 2. The activity was determined at the concentration of 0.002, 0.01 and 0.05 $\mathrm{mg} / \mathrm{ml}$. The scavenging activity was concentration dependent in all parts. Highest antioxidant potential was observed in stem $(35.9 \%)$ at the concentration level of 0.05 followed by root (29.6\%) and leave (19.4\%). The activity in the stem (35.9\%) was higher than standard ascorbic acid (28.2\%) at the concentration of $0.05 \mathrm{mg} / \mathrm{ml}$.

\section{Estimation of polyphenols}

The polyphenolic content in water and ethanol extract ranged from $2.2 \mathrm{mg} \%$ GA to $9.54 \mathrm{mg} \%$ GA. The highest polyphenol content was found in water extract of stem $(9.54 \pm .2 \mathrm{mg} \% \mathrm{GA})$. In ethanol extract, highest polyphenol content was found in root $(4.28 \pm .1 \mathrm{mg} \% \mathrm{GA})$, while stem and leaf extracts showed low content (Fig. 3).

\section{Estimation of flavonoids and tannin}

To estimate Flavonoids ethanol and water extracts were used and results are expressed as rutin equivalents (RE)/ $\mathrm{mg} \%$ of extract. The concentration of flavonoids in ethanol and water extracts is given in Fig. 4. The values in water extract ranged from $0.30 \mathrm{RE} / \mathrm{mg} \%$ of extract to $2.5 \mathrm{RE} / \mathrm{mg} \%$ of extract. Ethanol extract showed many fold high value of flavonoids. The values ranged from $0.79 \pm .01 \mathrm{RE} / \mathrm{mg} \%$ of extract to $20.0 \mathrm{RE} / \mathrm{mg} \%$ of extract. Highest flavonoids were found in ethanol extract of leaves $(20.0 \pm 0.9 \mathrm{RE} / \mathrm{mg} \%$ of extract followed by root $(10.6 \pm 0.2 \mathrm{RE} / \mathrm{mg} \%$ of extract).

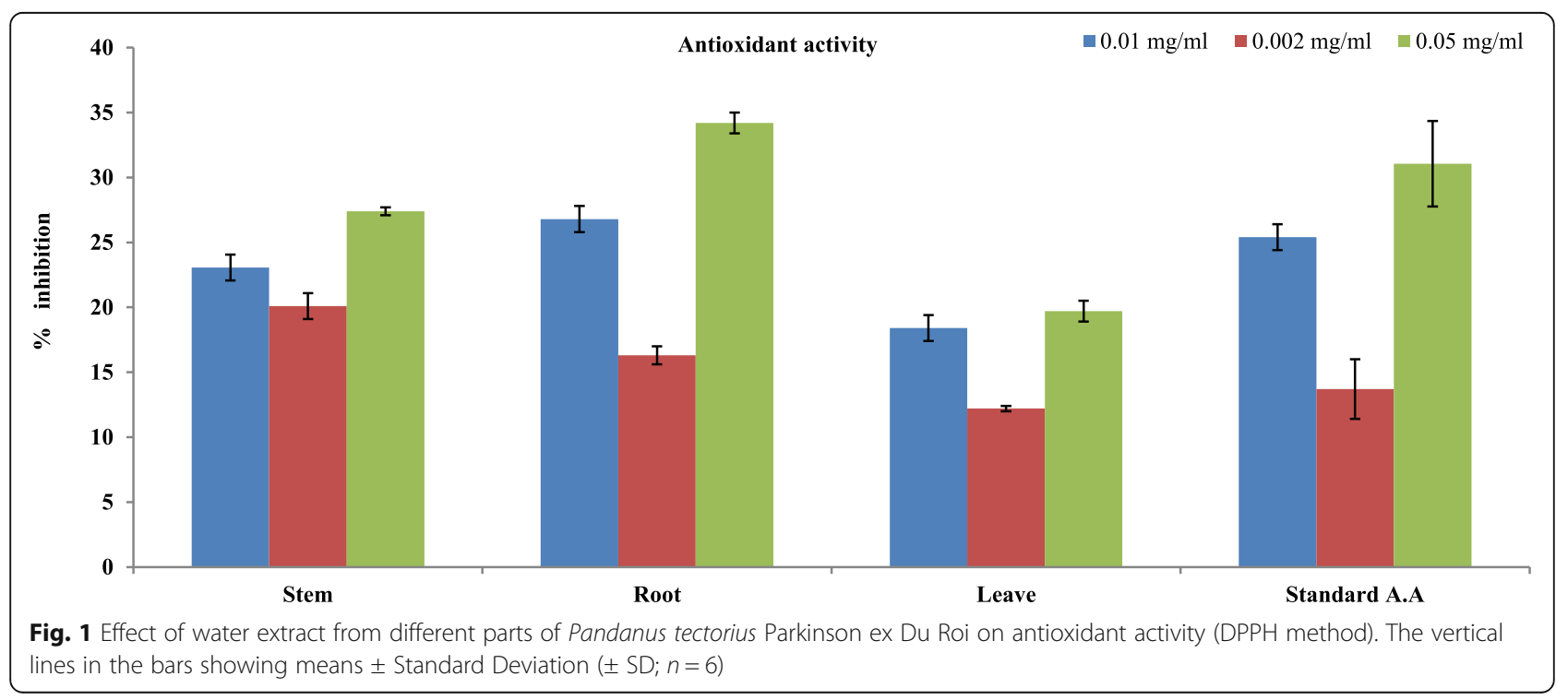




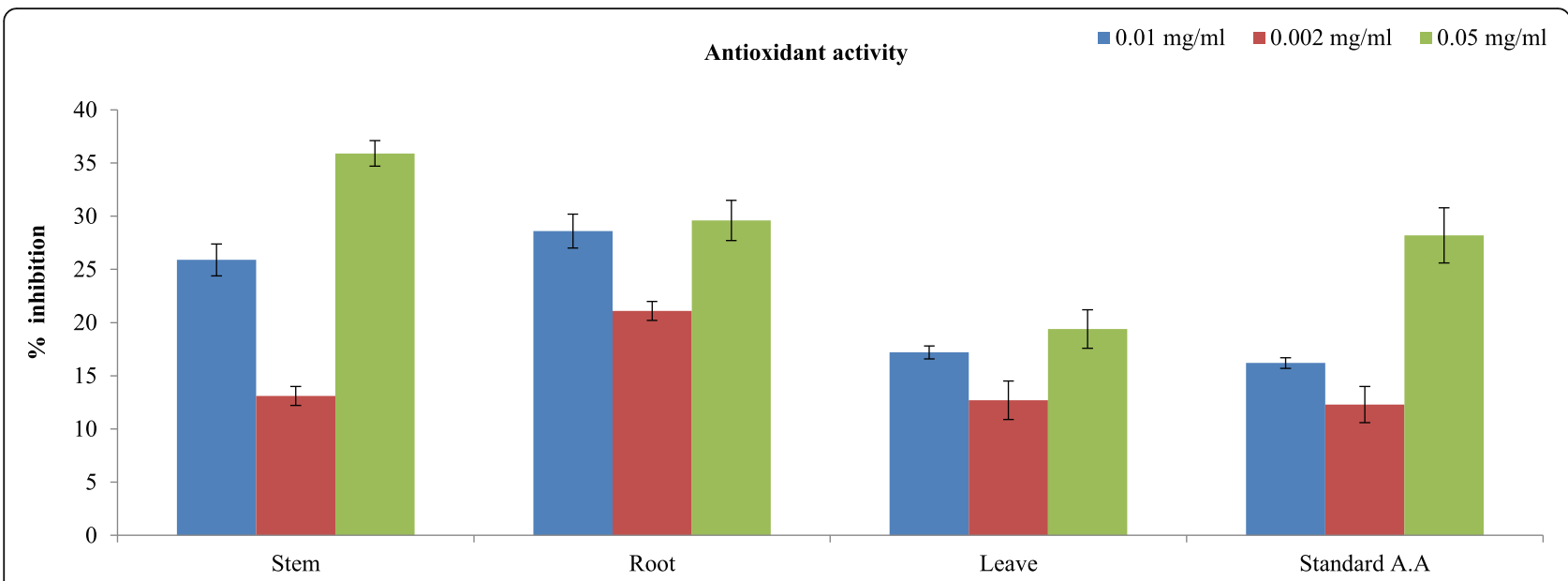

Fig. 2 Effect of ethanol extract from different parts of Pandanus tectorius Parkinson ex Du Roi on antioxidant activity (DPPH method). The vertical lines in the bars showing means \pm Standard Deviation $( \pm S D ; n=6)$

Tannin was determined in ethyl alcohol and water extracts of root, stem and leave. Water extracts revealed high levels of tannins in terms of $\mathrm{mg} \%(+)$-catechin in all three parts. The level of tannin in water extract of root $(46.2 \pm 2.4 \mathrm{mg} \% \quad(+)$-catechin $), \quad$ stem $\quad(66.4 \pm 0.2 \mathrm{mg} \%$ $(+)$-catechin), and leave $(41.7 \pm 1.3 \mathrm{mg} \%(+)$-catechin) was many fold higher than ethanol extract except leave extract of ethanol (49.5 $\pm 2.1 \mathrm{mg} \%$ (+)-catechin) (Fig. 4).

\section{Estimation of alkaloid and saponin}

The concentration of alkaloid and saponin in different parts of the plant are shown in Fig. 5. Highest alkaloid concentration was observed in leave $(0.948 \pm .015 \% \mathrm{w} / \mathrm{w})$ followed by stem $(0.766 \pm .01 \% \mathrm{w} / \mathrm{w})$ and root $(0.14 \pm$ $0.01 \% \mathrm{w} / \mathrm{w})$. Whereas, highest saponin level was observed in stem $(1.31 \pm 0.1 \% \mathrm{w} / \mathrm{w})$ followed by root $(0.99 \pm 0.06 \% \mathrm{w} / \mathrm{w})$ and leaves $(0.94 \pm 0.08 \% \mathrm{w} / \mathrm{w})$.

\section{Discussion}

In the present study root, stem and leaf of plant Pandanus tectorius Parkinson ex Du Roi were tested for their hypoglycemic potential in healthy and alloxan induced diabetic rats. The results showed that both water and ethanol extracts exhibited anti-hyperglycemia in normal rats, as well as in diabetic rat models. Medicinal plants have been reported to possess hypoglycemic

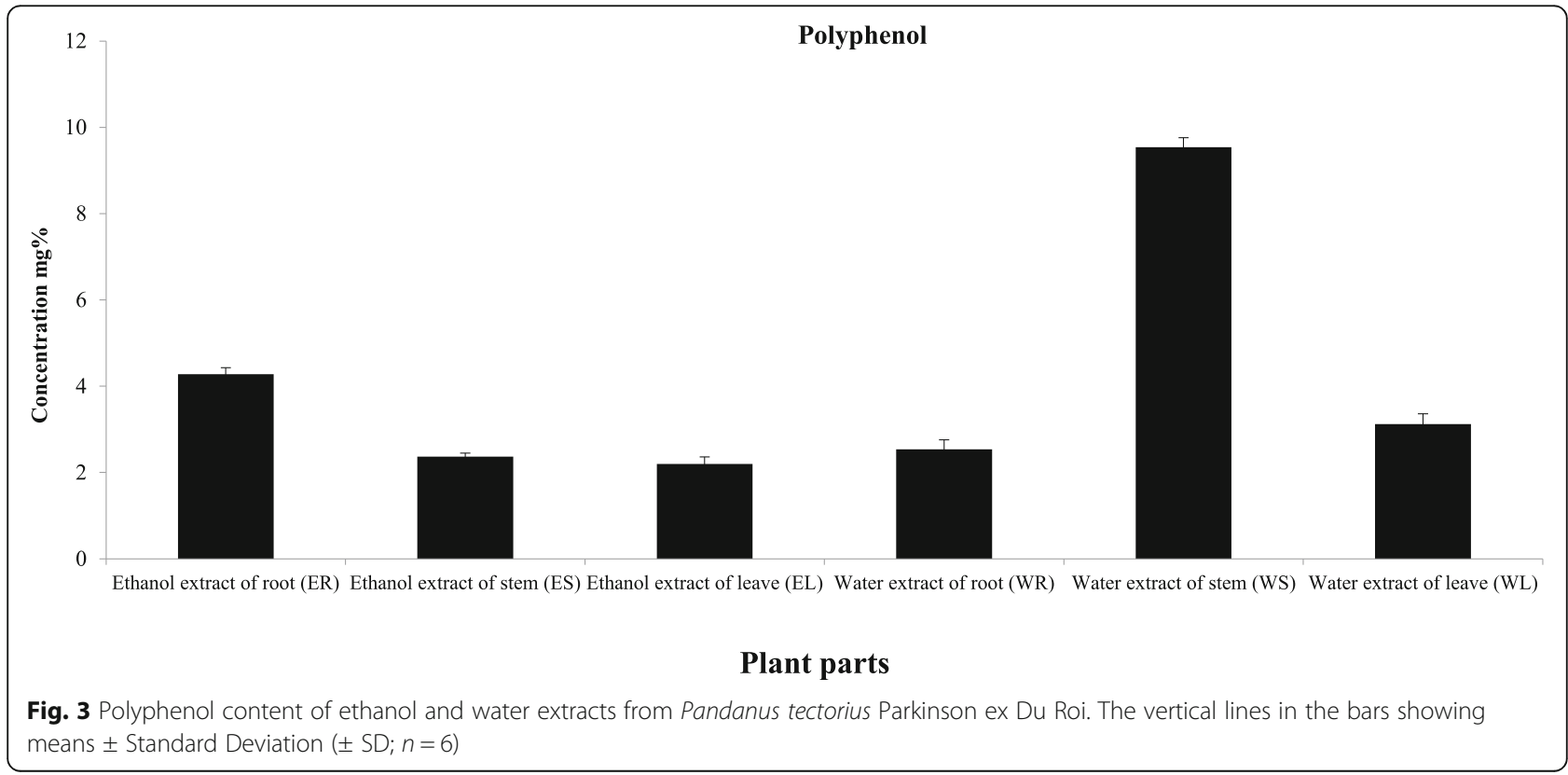




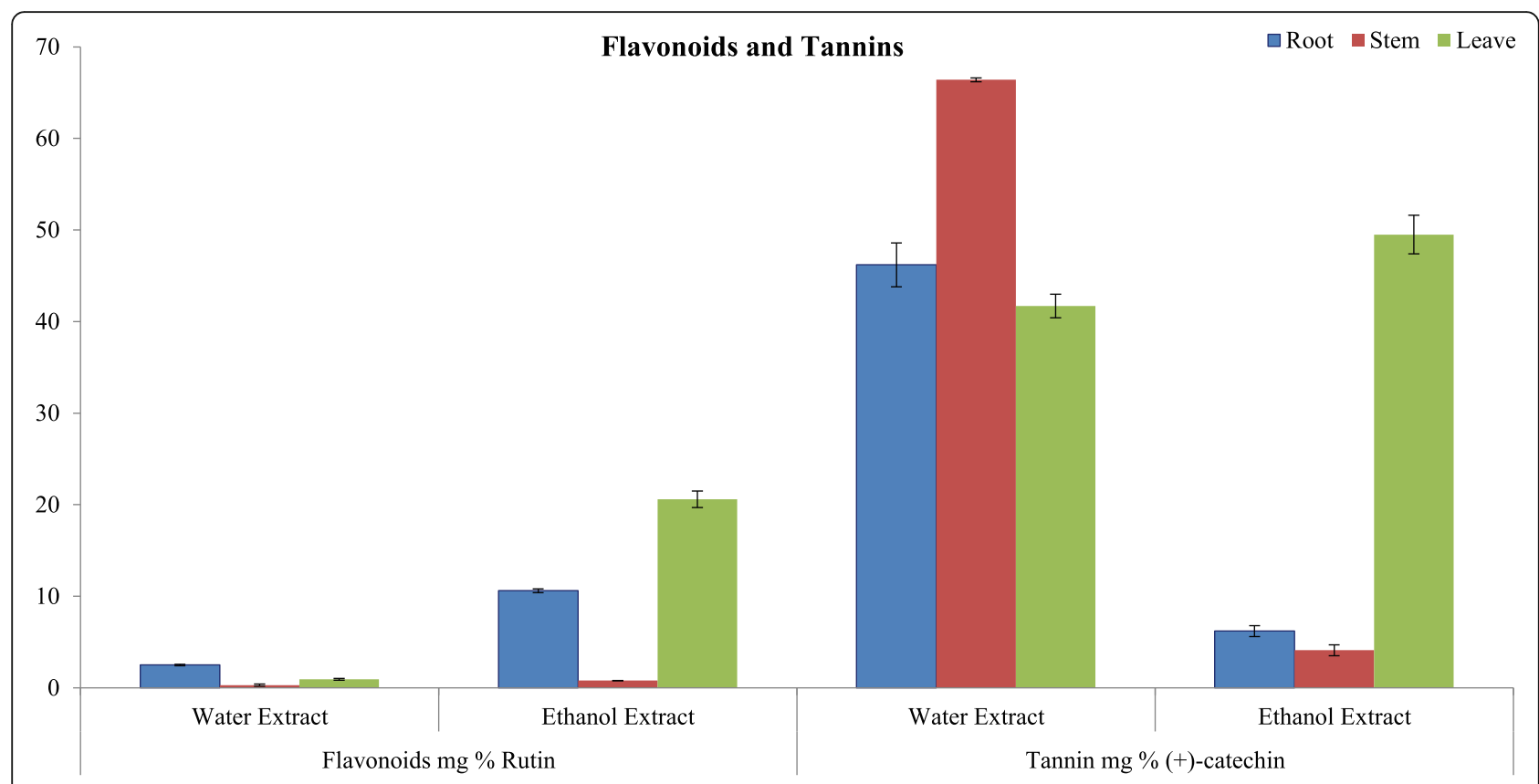

Fig. 4 Phytochemicals; flavonoids and tannin in different parts of Pandanus tectorius Parkinson ex Du Ro. The vertical lines in the bars showing means \pm Standard Deviation ( \pm SD; $n=3$ )

potential which can be used to treat diabetes mellitus [24]. Many mechanisms of action have been proposed by which extracts of medicinal plants produced hypoglycemia. The proposed mechanisms include the effect of plant material on $\beta$-cells of pancreas, which may diminish synthesis of insulin, or release, or cell regeneration. The plants also produce anti-diabetic effects by improving peripheral glucose utilization or enhancing the synthesis of liver glycogen or may inhibit absorption of glucose from intestine [25]. For anti-diabetic activity, plants are responsible via their capability to reestablish the function of pancreas either by increasing the secretion of hormone or by decreasing the absorption of glucose from intestine $[26,27]$. In this study water extract of root, stem $(65.98 \%)$ and leave displayed a marked reduction in serum glucose concentration in alloxan

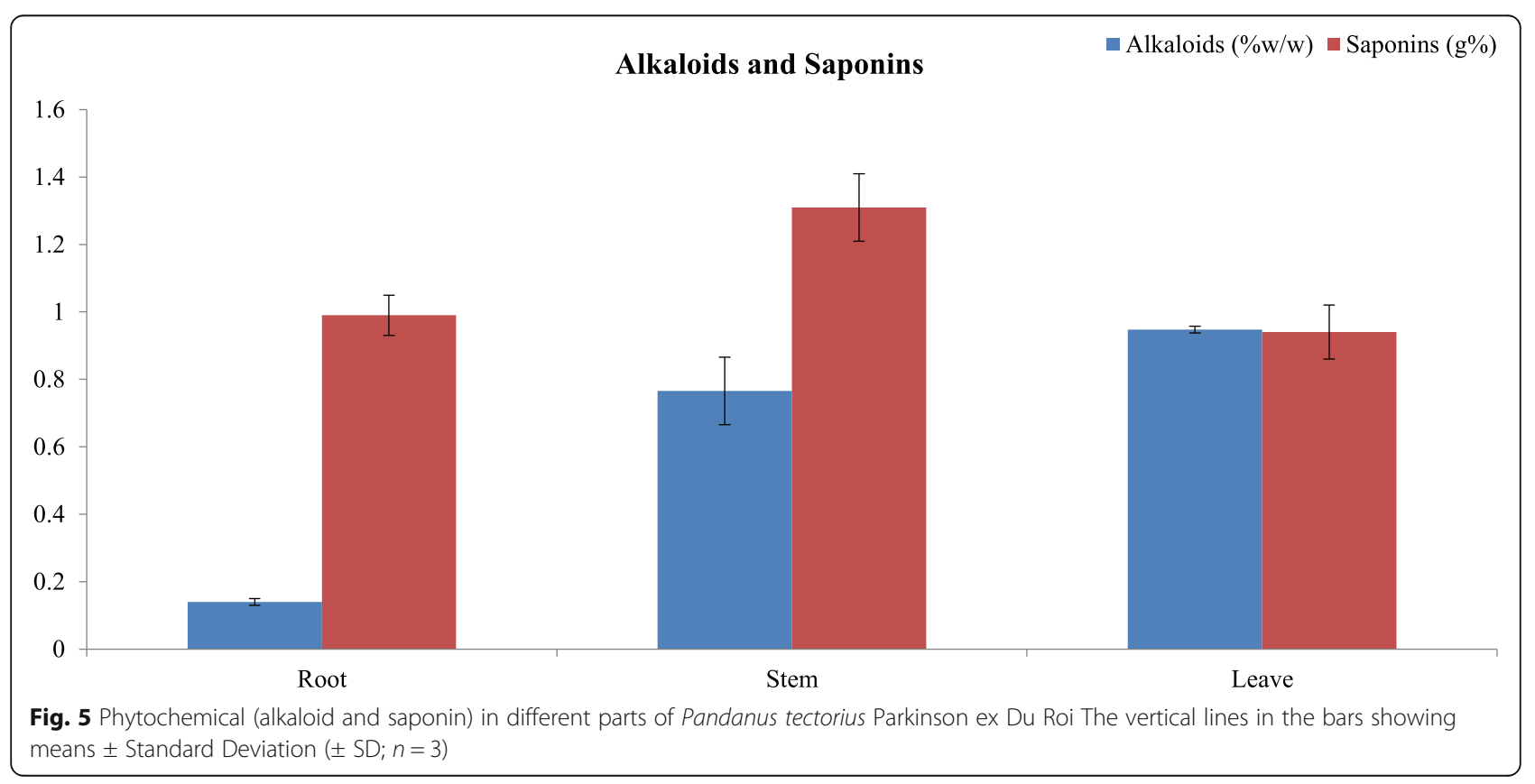


diabetic rats. Similarly, ethanol extract of root, stem and leave also significantly decreased the level of glucose in comparison with their respective diabetic control (untreated) rats, this indicates stimulation of insulin release from the pancreas [28]. Alloxan causes heavy destruction of pancreatic $\beta$-cells, which results in reduced synthesis and release of hormones from the pancreas. The normal functioning of insulin is impaired which causes hyperglycemia [29]. In our study alloxan induced hyperglycemia, but treatment with ethanol and water extract significantly reduced glucose level. The water extract of Euonymus alatus decreased the streptozotocin induced elevated level of serum glucose level [30]. Alloxan causes permanent damage to $\beta$-cells [31]. In our study alloxan treated rats after treatment with ethanol and water extract of root stem and leave demonstrated variable but significant reduction in glucose level, so we concluded that these extracts produced anti-diabetic effects by a mechanism other than the stimulation of insulin release from $\beta$-cells of pancreas.

Hyperlipidemia is characterized by enhanced levels of triglycerides, cholesterol, low density lipoprotein cholesterol (LDL-c). The results of the in vivo study revealed that both ethyl alcohol and water extracts of root, leave and stem significantly reduced the level of cholesterol, triglycerides, and LDL-c with subsequent increase in HDL-c in normal and diabetic rats in comparison with their respective control. All three extracts corrected hyperlipidemia. Hyperlipidemia is the leading endangerment for the premature development of heart disease like coronary artery disease, atherosclerosis and hypertension. Many studies on hyperlipidemia suggested that decrease in lipid profile: cholesterol, triglycerides and LDL-c and increase in HDL-c reduces risk of developing ischemic heart diseases [32]. Prolonged hyperglycemia produced more oxidative stress. Oxidation is one of the destructive activities in which various molecules are broken down. Oxidative stress is the main factor which relates hyperlipidemia with pathogenesis of atherosclerosis [33]. These reactive oxygen species react with lipids and cause lipid peroxidation, which results in membrane necrosis. Lipid peroxidation is declined which leads to curtailment in arterial wall cholesterol and deduction in atherosclerosis caused by hyperlipidemia [34]. In the study the coronary risk index (CRI) and atherogenic index (AI) increased in alloxan induced diabetic rats, whereas indexes reduced or came towards normal range after treatment with extract, this indicates reduction in risk for development of coronary disease. Several indices have been derived from lipid profile to establish an index for the prediction of cardiac risk, among these AI is considered as a strong index for predicting risk of ischemic diseases [35].
Free radicals also play a vital role in the production of secondary entanglement in diabetes mellitus and affect or impair the function of kidney, blood vessels, eye and nerves [36]. The elevated level of oxidative stress increases the lipid profile [37]. In this study different parts of P.tectorius showed significant antioxidant activity. There is a report that destruction of $\beta$ cells of pancreas is prevented by antioxidants [38]. The anti-diabetic activity of ethyl acetate fraction of $E$. alatus has been reported in alloxan treated mice evidenced by reduced plasma glucose, triglyceride and total cholesterol level with elevated SOD. This study also revealed that the ethyl acetate fraction contains flavonoids and polyphenols, including quercetin and kaempferol as main components with strong antioxidant activities [39].

Plasma urea and creatinine is widely accepted as a measurement of renal function [40]. In the study it was observed that urea and creatinine increased significantly in the alloxan diabetic control group. Administration of ethanol and water extract significantly decreased the serum level of both. The reduction in the level of these metabolites by the extract indicates the protective role of extracts against renal disorder due to diabetes [41, 42]. Anti-diabetic, anti-hyperlipidemia and nephronprotective (via reducing urea and creatinine level in serum of diabetic rats) has been reported [43].

Determination of cardiac and hepatic enzymes activity in serum or plasma is significantly important in order to diagnose the progression of disease. In this study the anti-diabetic activity and decrease in the level of ALP, ALAT, ASAT and LDH in alloxan induced diabetic rats might be due to the presence of antioxidant molecules in different parts of the plant. Certain enzymes are confined to certain tissues, and they enter in the blood only when these tissues are damaged. The presence of a significant increased amount of these specific enzymes in the blood reveals cell damage or destruction [44]. In present study enzyme activity of alanine aminotransferase (ALAT)/ serum glutamic pyruvic transaminase (SGPT), aspartate aminotransferase (ASAT)/ serum glutamic oxaloacetic acid (SGOT) alkaline phosphatase, and lactate dehydrogenase (LDH) in serum were reduced by the treatment of water and ethanol extracts of root, stem and leave as compared to alloxan induced diabetic rats. Attenuation of increased activities of all tested enzymes as compared to control rats indicate the protective and nontoxic nature of plant extract [45]. ALP is a liver marker enzyme and high level of enzyme in diabetic control indicates damage to structural integrity of liver. However diabetic rats treated with plant extract showed decreased in ALP level indicating healing effect of the extract. The transaminases ALAT and ASAT are also liver markers and used to detect toxicity to the liver [46]. Increased in activity of both transaminases in 
diabetic rats suggest damage of liver cells [47]. In this study LDH increased significantly in diabetic rats, and treatment with water and ethanol extract reduced the level towards normal. The increase in LDH activity after in diabetic rats may result from loss of membrane integrity [48].

Phytochemical estimation revealed the highest phenol content in water extract of stem. Extracts from different solvents showed a variable amount of phenol. Phenols are responsible for producing multiple biological effects including antioxidant and anti-diabetic [49, 50]. Our study also demonstrated the presence of a variable number of flavonoids, tannin, alkaloid and saponin in different parts of the plant. Many reports are available suggesting antioxidant and anti-diabetic and hypolipidemic potential of plants due to the presence of these constituents $[29,30,49]$.

\section{Conclusion}

Diabetes is a serious metabolic disorder affecting peoples worldwide. Long term hyperglycemia results in many complications like irregular functions of liver, heart and kidney. It also damages nerves, blood vessels and eyes. Treatment with oral hypoglycemic agents and insulin are not only expensive but also produce many adverse effects. We studied the anti-diabetic potential of water and ethanol extract of leaves, stem and root of $P$. tectorius in alloxan diabetic rats. This study demonstrated that all parts of plants have tremendous effect in lowering the blood glucose level and as well as attenuating the diabetes related complications like heart related problems and kidney dysfunction. In this study, different parts of $P$. tectorius showed good antioxidant activities and also showed presence of polyphenols. Dietary polyphenols have been reported to possess antidiabetic activity and inhibit $\alpha$-amylase and $\alpha$-glucosidase activities which may inhibit glucose absorption in the intestine and stimulate insulin secretion [51]. Polyphenols from $P$. tectorius could be a dietary therapy for the prevention and management of Type 2 diabetes. However, to confirm these effects and to make dietary recommendations for patients with type 2 diabetes, further studies are necessary.

\section{Abbreviations}

ALAT: Alanine aminotransferases; AST: Aspartate aminotransferases: ALP: Alkaline phosphatase; LDH: Lactate dehydrogenase; HDL: High density lipoprotein; LDL: Low density lipoprotein; CRl: Coronary artery risk index; Al: Atherogenic index; DPPH: 2,2-diphenyl-1-picryl-hydrazyl-hydrate; $P$. tectorius: Pandanus tectorius Parkinson ex Du Roi; DM: Diabetes mellitus

\section{Authors' contributions}

SS \& JA conceived and designed the study. SS and KH performed experimental work. SS \& NS analyzed and interpreted the results. AT and VS did chemical work. SS, H and NS wrote the manuscript. SE \& JA improved the manuscript. All authors read and approved the final manuscript.

\section{Funding}

Authors are thankful to the Dean, Faculty of Science, University of Karachi for financial assistance.

\section{Availability of data and materials}

Research data (Lab notebook) and materials can be provided on request.

\section{Declarations}

Ethics approval and consent to participate

The experiment was conducted according to the rules of Board of Advanced Studies \& Research/ Institutional Animal Ethics Committee (BASR No.01402/

SC dated March 05, 2013), University of Karachi.

\section{Consent for publication}

Not Applicable.

\section{Competing interests}

The authors declare that they have no competing interests.

\section{Author details}

'Department of Food Science \& Technology, University of Karachi, Karachi 75270, Pakistan. ${ }^{2}$ Institute of Biomedical Sciences, Dow University of Health Sciences, Karachi 75270, Pakistan. ${ }^{3}$ Department of Biochemistry, University of Karachi, Karachi 75270, Pakistan. ${ }^{4}$ Department of Botany, University of Karachi, Karachi 75270, Pakistan.

Received: 3 April 2020 Accepted: 26 April 2021

Published online: 28 May 2021

\section{References}

1. Aynalem SB, Zeleke AJ. Prevalence of diabetes mellitus and its risk factors among individuals aged 15 years and above in Mizan-Aman town, Southwest Ethiopia 2016: a cross sectional study. Int J Endocrinol. 2018. https://doi.org/10.1155/2018/9317987.

2. Tripathi V, Verma J. Current updates of Indian antidiabetic medicinal plants. Int J Res Pharm Chem. 2014:4:114-8.

3. Mazidi M, Kengne P, Mikhailidis DP, Toth PP, Ray KK, Banach M. Dietary food patterns and glucose/insulin homeostasis: a cross-sectional study involving 24,182 adult Americans. Lipids Health Dis. 2017;16:1-9.

4. Ma X, Chen Z, Wang L, Wang G, Dong X, Wen B, et al. The pathogenesis of diabetes mellitus by oxidative stress and inflammation: its inhibition by berberine. Front Pharmacol. 2018. https://doi.org/10.3389/fphar.2018.00782.

5. Phaniendra A, Jestadi DB, Periyasamy L. Free radicals: properties, sources, targets, and their implication in various diseases. Indian J Clin Biochem. 2015:30(1):11-6. https://doi.org/10.1007/s12291-014-0446-0.

6. Bellou V, Belbasis L, Tzoulaki I, Evangelou E. Risk factors for type 2 diabetes mellitus: an exposure-wide umbrella review of meta-analysis. PLoS One. 2018;13(3):e0194127. https://doi.org/10.1371/journal.pone.0194127.

7. Lennarz WJ, Lane MD. Encyclopedia of biological chemistry. 2nd ed. London: Academic; 2013.

8. Rajaram K. Antioxidant and antidiabetic activity of Tectona grandis Linn., in alloxan induced albino rats. Asian J Pharm Clin Res. 2013;6:174-7.

9. Zaid H, Mahdi AA, Tamrakar AK, Saad B, Razzaque MS, Dasgupta A. Natural active ingredients for diabetes and metabolism disorders treatment. Evi Based Complement Altern Med. 2016;2016:1-2. https://doi.org/10.1155/201 6/2965214.

10. Lim TK. Pandanus tectorius. In: Edible medicinal and non- medicinal plants. Dordrecht: Springer; 2012. p. 136-46. https://doi.org/10.1007/978-94-007-4 053-2_20.

11. Wu C, Zhang X, Zhang X, Luan H, Sun G, Sun X, et al. The caffeoylquinic acid-rich Pandanus tectorius fruit extract increases insulin sensitivity and regulates hepatic glucose and lipid metabolism in diabetic db/db mice. J Nutr Biochem. 2014;25(4):412-9. https://doi.org/1 0.1016/j.jnutbio.2013.12.002.

12. Baba S, Chan HT, Kezuka M, Inoue T, Chan EWC. Artocarpus altilis and Pandanus tectorius: two important fruits of Oceania with medicinal values. Emir J Food Agric. 2016;28(8):531-9. https://doi.org/10.9755/ejfa.2 016-02-207. 
13. Zhang X, Guo P, Sun G, Chen S, Yang M, Fu N, et al. Phenolic compounds and flavonoids from the fruits of Pandanus tectorius Parkinson ex Du Roi Soland. J Med Plants Res. 2012;6:2622-6.

14. Zhang M, Lv XY, Li J, Xu ZG, Chen L. The characterization of high-fat diet and multiple low-dose streptozotocin induced type 2 diabetes rat model. Exp Diabetes Res. 2008;2008:1-9. https://doi.org/10.1155/2008/ 704045

15. Mertz DP. "Atherosclerosis-index" (LDL/HDL): risk indicator in lipid metabolism disorders. Med Klin. 1980;75:159-1.

16. Tariq A, Ara J, Sultana V, Ehteshamul-Haque S, Athar M. Antioxidant potential of seaweeds occurring at Karachi coast of Pakistan. J Appl Bot Food Qual. 2011;84:207-2.

17. Jimenez-Escrig A, Jimenez-Jimenez I, Pulido R, Saura-Calixto F. Antioxidant activity of fresh and processed edible seaweeds. J Sci Food Agric. 2001;81: 585-8.

18. Chandini SK, Ganesan P, Bhaskar N. In vitro antioxidant activities of three selected brown seaweeds of India. Food Chem. 2008;107(2):707-3. https:// doi.org/10.1016/j.foodchem.2007.08.081.

19. Harborne JB. Phytochemical methods: a guide to modern techniques of plant analysis. 2nd ed. London: Chapman and Hall; 1973.

20. Obdoni BO, Ochuko PO. Phytochemical studies and comparative efficacy of the crude extracts of some homostatic plants in Edo and delta states of Nigeria. Global J Pure Appl Sci. 2001;8:203-8.

21. Julkunen-Titto R. Phenolic constituents in the leaves of northern willow: methods for the analysis of certain phenolics. J Agric Food Chem. 1985: 33(2):213-7. https://doi.org/10.1021/jf00062a013.

22. Chang $\mathrm{C}$, Yang $\mathrm{M}$, Wen $\mathrm{H}$, Chern J. Estimation of total flavonoid content in propolis by two complementary colorimetric methods. J Food Drug Anal. 2002;10:178-2

23. Armitage P, Berry G, Matthews JNS. Statistical methods in medical research. 4th ed. Oxford: Wiley; 2001

24. Arumugam G, Manjula P, Paari N. A review: anti diabetic medicinal plants used for diabetes mellitus. J Acute Dis. 2013;2(3):196-200. https://doi.org/1 0.1016/S2221-6189(13)60126-2.

25. Romila Y, Mazumder PB, Choudhury MD. A review on antidiabetic plants used by the people of Manipur characterized by hypoglycemic activity. J Sci Technol Biol Environ Sci. 2010;6:167-5.

26. Ali KM, Chatterjee K, De D, Bera TK, Ghosh D. Efficacy of aqueous extract of seed of Holarrhena antidysenterica for the management of diabetes in experimental model: a correlative study with anti-hyperlipidemic activity. Int J Appl Res Nat Prod. 2009;2(3):13-21.

27. Kujur RS, Singh V, Ram M, Yadava HN, Singh KK, Kumari S. Antidiabetic activity and phytochemical screening of crude extract of Stevia rebaudiana in alloxan induced diabetic rats. Pharm Res. 2010;2:258-3.

28. Ojezele MO, Abatan OM. Hypoglycemic and coronary risk index lowering effects of Bauhinia thoningii in alloxan induced diabetic rats. Afr Health Sci. 2011:11:85-9.

29. Sikarwar MS, Patil MB. Antidiabetic activity of Pongamia pinnata leaf extracts in alloxan-induced diabetic rats. Int J Ayurveda Res. 2010;1(4):199-4. https:// doi.org/10.4103/0974-7788.76780.

30. Zhai X, Lenon GB, Xue CC, Li CG. Euonymus alatus: a review on its phytochemistry and antidiabetic activity. Evid Based Complement Altern Med. 2016. https://doi.org/10.1155/2016/9425714.

31. Rohilla A, Ali S. Alloxan induced diabetes: mechanisms and effects. Int J Res Pharm Sci. 2012:3:819-3.

32. Nelson RH. Hyperlipidemia as a risk factor for cardiovascular disease. Prim Care. 2013:40(1):195-1. https://doi.org/10.1016/j.pop.2012.11.003.

33. Yang $X$, Li Y, Li Y, Ren $X$, Zhang $X$, Hu D, et al. Oxidative stress-mediated atherosclerosis: mechanisms and therapies. Front Physiol. 2017;8. https://doi. org/10.3389/fphys.2017.00600.

34. Patil K, Dhande S, Kadam V. Antihyperlipidemic and antioxidant activity of aerial parts of Swertia chirata (Buch-Ham) in poloxamer 407 induced hyperlipidemic rats. Int J Phytopharm. 2014;5:221-6.

35. Grundy SM, Benjamin IJ, Burke GL, Chait A, Eckel RH, Howard BV, et al. Diabetes and cardiovascular disease: a statement for healthcare professionals from the American heart association. Circulation. 1999;100(10): 1134-6. https://doi.org/10.1161/01.CIR.100.10.1134.

36. Kazemi T, Hajihosseini M, Moossavi M, Hemmati M, Ziaee M. Cardiovascular risk factors and atherogenic indices in an Iranian population: Birjand east of Iran. Clin Med Insights Cardiol. 2018;12:117954681875928. https://doi.org/1 $0.1177 / 1179546818759286$
37. Le NA. Lipoprotein-associated oxidative stress: a new twist to the postprandial hypothesis. Int J Mol Sci. 2015;16:401-9.

38. Wang J, Wang H. Oxidative stress in pancreatic beta cell regeneration. Oxid Med Cell Longev. 2017. https://doi.org/10.1155/2017/1930261.

39. Fang XK, Gao Y, Yang HY. Alleviating effects of active fraction of Euonymus alatus abundant in flavonoids on diabetic mice. Am J Chin Med. 2008; 36(01):125-40. https://doi.org/10.1142/S0192415X08005643.

40. Pandya D, Nagrajappa AK, Ravi KS. Assessment and correlation of urea and creatinine levels in saliva and serum of patients with chronic kidney disease, diabetes and hypertension-a research study. J Clin Diagn Res. 2016;10:ZC58-62.

41. Joy KL, Kuttan R. Anti-diabetic activity of Picrorrhiza kurroa extract. J Ethnopharmacol. 1999;67(2):143-8. https://doi.org/10.1016/S0378-8741 (98)00243-8.

42. Atangwho IJ, Ebong PE, Eteng MU, Eyong EU, Obi AU. Effect of Vernonia amygdalinadel leaf on kidney function of diabetic rats. Int J Pharm. 2007;3: $143-8$.

43. Li YJ, Gong MX, Lai YY, Wang Q, Chen YH, Tian PF. Pharmacological effects of different extract fractions from Guijianyu (Euonymus alatus) on diabetic rats. J Beijing Univ Chin Med. 2010;33:179-2.

44. Nelsen EM, Newman DB, Sweetser S. 52-year-old man with liver enzyme abnormalities and elevated ferritin level. Mayo Clin Proc. 2012;87(1):94-7. https://doi.org/10.1016/j.mayocp.2011.08.004.

45. Sunmonu TO, Afolayan AJ. Evaluation of antidiabetic activity and associated toxicity of Artemisia afra aqueous extract in wistar rats. Evid Based Complement Altern Med. 2013. https://doi.org/10.1155/2013/929074.

46. Rahman MF. Effects of vepacide (Azadirachta indica) on aspartate and alanine aminotransferase profiles in a subchronic study with rats. Human Exp Toxicol. 2001;20(5):243-9. https://doi.org/10.1191/096032701678227730.

47. Yazdi HB, Hojati V, Shiravi A, Hosseinian S, Vaezi G, Hadjzadeh MAR. Liver dysfunction and oxidative stress in streptozotocin-induced diabetic rats: protective role of Artemisia turanica. Aust J Pharm. 2019;22:109-4.

48. Nasry MR, Abo-Youssef AM, El-Latif HA. Anti-diabetic activity of the petroleum ether extract of guar gum in streptozotocin-induced diabetic rats: a comparative study. Beni-Suef Univ J Basic Appl Sci. 2013;2:51-9.

49. Ahmed MF, Rao AS, Ahemad SK, Ibrahim M. Phytochemical studies and antioxidant activity of Melia azedarach Linn leaves by DPPH scavenging assay. Int J Pharm Appl. 2012;3:271-6.

50. Semwal DK, Bamola A, Rawat U. Chemical constituents of some antidiabetic plants. Univ J Phytochem Ayur Heig. 2007;2:40-8.

51. Kim Y, Keogh JB, Clifton PM. Polyphenols and glycemic control: review. Nutrients. 2016;8(1). https://doi.org/10.3390/nu8010017.

\section{Publisher's Note}

Springer Nature remains neutral with regard to jurisdictional claims in published maps and institutional affiliations.

\section{Submit your manuscript to a SpringerOpen ${ }^{\circ}$ journal and benefit from:}

- Convenient online submission

- Rigorous peer review

- Open access: articles freely available online

- High visibility within the field

- Retaining the copyright to your article

Submit your next manuscript at $>$ springeropen.com 